\title{
Patterns of Hospice Use in Patients Dying from Hematologic Malignancies
}

\author{
Amy Sexauer, BS, MD, PhD, ${ }^{1}$ M. Jennifer Cheng, MD, ${ }^{2}$ Louise Knight, MSW, ${ }^{3}$ Anthony W. Riley, MD, ${ }^{4}$ \\ Lauren King, BSN, MSN, ${ }^{2}$ and Thomas J. Smith, MD, FACP, FASCO, FAAHPM ${ }^{3}$
}

\begin{abstract}
Background: Hospice brings substantial clinical benefits to dying patients and families but is underutilized by patients dying of hematologic malignancies (HM); nationwide, only $2 \%$ of HM patients use hospice. There are 70,000 deaths among U.S. patients with hematologic malignancies yearly.

Objective: We measured the use and length of stay (LOS) in hospice among patients with HMs at a large academic cancer center.

Design: This was a single center retrospective review of adult patients ( $\geq 18$ years) with lymphoma, leukemia, myelodysplastic syndrome, aplastic anemia, and multiple myeloma referred for hospice.

Measurements: Information included demographics, transplant, hospice type, LOS, and use of "expanded access" services.

Results: Fifty-nine patients were referred to hospice, and 53 utilized hospice services, 25\% of 209 HM decedents. Thirty-five received home hospice and 18 used inpatient hospice. The median home hospice LOS was nine days (SD 13) and inpatient hospice six days (SD 10). Nine patients with "expanded access" hospice received only a few blood transfusions, and none received radiation.

Conclusions: HM patients are referred late or never for hospice services. Studies evaluating earlier integration of palliative and hospice care with usual HM care are warranted. We present a one-page negotiation form that we have found useful in negotiations among HM physicians, hospice medical directors, and payers.
\end{abstract}

\section{Introduction}

$\mathbf{P}$ ALliative CARE (PC) concurrent with oncology care and transition to hospice when appropriate is recommended by the American Society of Clinical Oncology, because the evidence shows equal or better survival, reduced symptom burden, and better outcomes for caregivers, at an affordable cost. ${ }^{1}$ This continues the recognition of hospice as the best care near the end of life., ${ }^{2,3}$ Both hospice and palliative care discern choices near the end of life, allow more home care and death at the preferred place, and reduce readmissions. ${ }^{4,5}$

Palliative care and hospice use has been limited in patients with hematologic malignancies (HMs, here defined as refractory leukemia, refractory lymphoma, myelodysplastic syndrome, and refractory myeloma). Fewer than $2 \%$ of $\mathrm{HM}^{6}$ decedents use hospice, ${ }^{7}$ and there is no published experience about hospice or PC programs for HM despite the potential for improving care in a seriously ill population. ${ }^{8-10}$
The limited use has been because of perceived HM special needs including a less predictable course, curative intent, discordance between patient and physician expectations, ${ }^{11}$ and the perceived ongoing need for expensive antineoplastics, antibiotics, and transfusions. There is also a mismatch in what hospices call "aggressive" care such as transfusions and radiation are accepted usual care to patients and families and health care professionals. ${ }^{12}$ The available evidence that routine care such as red blood cell transfusions help hospice patients too ${ }^{13}$ but they are often not a covered benefit due to expense.

This limited use is a significant problem for the 70,000 or more patients who die of HMs in the United States each year. Despite advances in treatment, there are still substantial deaths among patients with HMs: leukemia (23,540), lymphoma (20,130), myeloma (10,710), and myelodysplastic syndrome $(>10,000) .{ }^{14,15}$ These deaths are reasonably predictable, as shown in Table 1, with survival figures of contemporary patients eligible for clinical trials. Actual

\footnotetext{
${ }^{1}$ Oncology Department, ${ }^{2}$ Palliative Medicine Department, Johns Hopkins School of Medicine, Baltimore, Maryland.

${ }^{3}$ Sidney Kimmel Comprehensive Cancer Center, Johns Hopkins Medical Institutions, Baltimore, Maryland.

${ }^{4}$ Gilchrist Hospice, Towson, Maryland.

Accepted September 3, 2013.
} 
Table 1. The Survival of HM Patients Once Refractory to Usual Care

\begin{tabular}{|c|c|c|c|c|}
\hline & $\begin{array}{l}\text { Progression free } \\
\text { survival (median) }\end{array}$ & $\begin{array}{l}\text { Overall survival } \\
\quad \text { (median) }\end{array}$ & $\begin{array}{l}\text { Range and } \\
\text { one-year survival }\end{array}$ & Reference \\
\hline $\begin{array}{l}\text { Myeloma, refractory } \\
\text { to bortezomib and } \mathrm{iMiDs}{ }^{37}\end{array}$ & 5.0 months & 9.0 months & $\begin{array}{l}60 \% \text { dead, } 40 \% \\
\text { alive at one year. }\end{array}$ & $\underset{2011}{\text { Kumar, et al., }}$ \\
\hline $\begin{array}{l}\text { Lymphomas, refractory, } \\
\text { on modern phase II trials }\end{array}$ & 2.8 months & $\begin{array}{l}6.4 \text { months for } \\
\text { aggressive } \\
\text { lymphomas }\end{array}$ & $\begin{array}{l}65 \% \text { dead, } 35 \% \\
\text { alive at one year. }\end{array}$ & $\begin{array}{l}\text { Witzig, et al., } \\
2011\end{array}$ \\
\hline Myelodysplastic syndrome ${ }^{39}$ & NS & $\begin{array}{l}4.3 \text { months after } \\
\text { failure } \\
\text { of decitabine }\end{array}$ & $\begin{array}{l}72 \% \text { dead, } 28 \% \\
\text { alive at one year. }\end{array}$ & $\begin{array}{l}\text { Kadia, et al., } \\
2011\end{array}$ \\
\hline $\begin{array}{l}\text { Acute leukemia, relapsed } \\
\text { or refractory and not fit } \\
\text { for usual chemotherapy }\end{array}$ & None & 3.0 months & All dead within one year. & $\begin{array}{l}\text { Al-Ali, et al., } \\
2011\end{array}$ \\
\hline CML refractory to $\mathrm{TKIs}^{41}$ & $\begin{array}{l}5.0 \text { months, in } \\
\text { advanced phase } \\
3.0 \text { months in } \\
\text { blast phase }\end{array}$ & 20.0 months & $\begin{array}{l}69 \% \text { dead, } 31 \% \\
\text { alive at } 13.0 \text { months. } \\
\text { BP } 80 \% \text { dead. } \\
\text { AP } 20 \% \text { dead. } \\
\text { CP } 10 \% \text { dead. }\end{array}$ & $\begin{array}{l}\text { Garg, et al., } \\
2009\end{array}$ \\
\hline $\begin{array}{l}\text { CML, refractory to TKIs, } \\
\text { with omacetaxine }\end{array}$ & $\begin{array}{l}\text { Median } \\
\quad 7.7 \text { months }\end{array}$ & $\begin{array}{l}5.0 \text { months } \\
\text { in nonresponders }\end{array}$ & $\begin{array}{l}\text { Good hematologic } \\
\text { response in } 77 \% \text {, but if } \\
\text { not, } 75 \% \text { dead in one year. }\end{array}$ & $\begin{array}{l}\text { Cortes, et al., } \\
2012\end{array}$ \\
\hline $\begin{array}{l}\text { Chronic lymphoid leukemia, } \\
\text { refractory to multiple drugs }\end{array}$ & & $\begin{array}{l}10.0 \text { months in } \\
\text { nonresponders } \\
\text { to ofatumumab }\end{array}$ & $\begin{array}{l}55 \% \text { dead, } 45 \% \\
\text { alive at one year. }\end{array}$ & $\begin{array}{l}\text { Wierda, et al., } \\
2010\end{array}$ \\
\hline
\end{tabular}

AP, accelerated phase; BP, blast phase; CML, chronic myeloid leukemia; CP, chronic phase; ECOG, Eastern Cooperative Oncology Group; iMiDs, immune modulating drugs; TKI, tyrosine kinase inhibitor.

community survival will be worse, since many patients have poor performance status and are not fit for clinical trials.

The experience of at least some patients, families, and hospice and palliative medicine (HPM) professionals is that HM patients are routinely given "aggressive care" (defined as chemotherapy within 14 days of death, no hospice use, or hospice use for $<3$ days) ${ }^{16}$ at the end of life. These patients can suffer the consequences of poorly managed death including death in the hospital instead of home, intensive care unit (ICU) use when not appropriate or wanted, and prolonged grief and bereavement in the survivors. This also leads to poor use of scarce resources ${ }^{17}$ such as limited ICU beds ${ }^{18}$ and moral distress among health care professionals. ${ }^{19}$

We studied the use of hospice by HM decedents at Johns Hopkins Sidney Kimmel Comprehensive Cancer Center ( JH SKCCC) to understand current patterns and inform a possible intervention.

\section{Methods}

The aim of this retrospective study was to review the experience of HM patients with hospice, since so little is known. We obtained the number of HM deaths in 2010-2012 from the SKCCC Tumor Registry and from our hospice referral list. We reviewed corresponding hospice referrals and acceptances, tracked routinely by social work departments. We created a spreadsheet of decedents, disease (obtained from the electronic medical record), date of death, age, gender, hospice length of stay (LOS), and "expanded access" hospice use (defined as hospice that allows patients to receive some standard medical treatments while concurrently enrolled in hospice). We reviewed the electronic medical

record and hospice record for use of transfusions, antibiotics, and radiation.

\section{Results}

There were 209 HM decedents in 2010-2012. Fifty-nine HM patients were referred to hospice over this period, and 53

Table 2. Demographics and Diagnosis OF THE POPUlation

Mean $64.2 ;$ median $66 ;$
range $31-84$ years

Gender

Transplanted

Hospice service site

"Open access"

Hematologic malignancy category

Acute myelogenous leukemia

Myelodysplastic syndrome

MDS/AML

Acute lymphocytic leukemia

CML blast crisis

T-cell lymphoma

Aplastic Anemia

Diffuse large B cell lymphoma

Follicular lymphoma

Hodgkin lymphoma

Burkitt lymphoma

Mantle cell lymphoma

Non-Hodgkin lymphoma

Multiple myeloma

Total
Female 30/59; male 29/59

11

Home: 35; inpatient: 18

9
$N$

$N$

8

7

7

1

3

1

5

1

4

1

1

1

8

59 
patients (25\% of 209) accepted hospice (see Table 2). Of the 53 patients, 35 received home and 18 inpatient hospice. One 84-year-old lymphoma patient was excluded from the study, as she was entered into hospice by her primary care physician, not the HM malignancy team, and was an extreme outlier with a hospice stay of 108 days. No patients were excluded due to incomplete data on survival or hospice entry. The median home hospice LOS was 9 days (SD 13; range 150 days) and inpatient hospice 6 days (SD 10; range 3-51 days). Nine patients with "expanded access" hospice received only a few blood transfusions, and one patient was approved for radiation therapy but got only one fraction before being admitted to inpatient hospice.

\section{Discussion}

Patients who died of hematologic malignancies used hospice about $25 \%$ of the time for a median of nine outpatient and six inpatient days. This is better than the national rate of $2 \%$ for HM decedents, but means that $75 \%$ of patients never experienced the benefits of hospice including good symptom management, bereavement programs, less cost, ${ }^{20}$ and even slightly lower mortality of the surviving spouse. ${ }^{21}$ Among cancer patients who were seriously ill enough to have been in the hospital during their last six months of life between 20032007 , including $9 \%$ of patients with hematologic malignancies, the average LOS in hospice was eight days. ${ }^{22}$ In that Medicare cohort with an average age of 78 years, $30 \%$ died in the hospital, $25 \%$ were in the ICU in their last month of life, only $54 \%$ ever used hospice, and the average LOS in hospice was just eight days. ${ }^{22}$ The median hospice LOS for U.S. alldiagnosis patients is 19.1 days, ${ }^{23}$ double that observed here. The Center for Medicare Services lists 40 days as the average hospice LOS in 2009 for "blood/lymph CA" patients, compared to 45 days for lung cancer patients, but is not a useful comparison as it does not differentiate between those who received any treatment and those who entered into hospice at diagnosis due to debility or comorbid conditions. ${ }^{24}$ No information is available about other younger U.S. cohorts. In addition to no referral, "late" referral to hospice means that patients may have less chance of having their end-of-life wishes known and honored, with more chance of dying with aggressive care or in the hospital rather than at home. ${ }^{25}$

"Expanded access" hospice with a negotiated plan of treatment may allow patients to benefit from hospice care while still receiving needed services. ${ }^{26}$ We have created a form (see Table 3) for the HM, palliative care, and hospice physician to negotiate some the most common issues while on conference call. This form was created by the authors (TJS, WAR) in conjunction with the HM physicians at SKCCC, particularly Drs. Richard Jones and Richard Ambinder. This approach has been helpful in negotiating some difficult cases.

Hospice is underutilized due to a lack of recognition of hospice eligibility. In one study of 209 hospital decedents, $60 \%$ were eligible for hospice on their penultimate admission, yet only $14 \%$ had any discussion of hospice. Of 46 admissions to the hematology/oncology service, 40 were hospice eligible but only 5 had any discussion about hospice. The authors concluded that providers need to be trained to recognize the slow declines of chronic illness, to know the eligibility criteria, and to know the benefits of hospice. $^{27}$ Those who used hospice had less aggressive endof-life care, and markedly lower hospital readmissions and costs. ${ }^{28}$ The limited data show that exposure to palliative care prior to hospice is also strongly associated with better caregiver quality of life, likely from symptom management and better understanding of prognosis and goals. ${ }^{29}$ If palliative care is involved in the care of patients, the number of appropriate patients discharged from hospital to hospice

Table 3. Issues to Negotiate Before Enrolling a Hematologic Malignancy Patient in Expanded Access Hospice Care

\begin{tabular}{|c|c|c|}
\hline Issue & $\begin{array}{c}\text { Heme } \\
\text { malignancy } \\
\text { perspective }\end{array}$ & Hospice medical director perspective \\
\hline Red blood cell transfusions & $\mathrm{OK}$ & Transfuse if symptomatic. \\
\hline Platelet transfusions & $\mathrm{OK}$ & Transfuse if bleeding, not just for a number. \\
\hline Use of IV fluids & OK & $\mathrm{OK}$ \\
\hline Use of TPN & $\mathrm{OK}$ & $\mathrm{OK}$ \\
\hline Use of IV antibiotics & $\mathrm{OK}$ & $\begin{array}{l}\text { Depends on the cost of the regimen. Would need } \\
\text { to have the specific regimen priced out before approval. }\end{array}$ \\
\hline $\begin{array}{l}\text { Use of expensive antibiotics (Voriconizole, } \\
\text { Vfend }^{\circledR} \text { is } \$ 25-\$ 100 / \text { day) }\end{array}$ & $\mathrm{OK}$ & $\begin{array}{l}\text { Not affordable due to unit cost and the duration } \\
\text { of therapy which is often long-term. }\end{array}$ \\
\hline Use of prophylactic antibiotics & $\mathrm{OK}$ & $\begin{array}{l}\text { Depends upon the specific regimen, and cost. Low-cost } \\
\text { alternatives available, e.g., TMP-SMX. }\end{array}$ \\
\hline Procrit $^{\circledR} /$ Aranesp ${ }^{\circledR}$ & OK & Not affordable. \\
\hline Routine labs, e.g. CBC & $\mathrm{OK}$ & $\mathrm{OK}$ \\
\hline Specialty labs & $\mathrm{OK}$ & Usually not $\mathrm{OK}$-rationale must be justified. \\
\hline $\begin{array}{l}\text { PleurX }{ }^{\circledR} \text { catheters ( } \$ 900 \text { starter kit, } \\
\$ 45+\text { bag) }\end{array}$ & $\mathrm{OK}$ & $\begin{array}{l}\text { OK but urge the placement of the catheter } \\
\text { while in the hospital. }\end{array}$ \\
\hline Outpatient paracentesis/thoracentesis & OK & $\mathrm{OK}$ \\
\hline Radiation therapy & $\mathrm{OK}$ & $\begin{array}{l}\text { OK. We urge that the simulation be done prior to discharge } \\
\text { from the hospital, and consider hypofractionation. }\end{array}$ \\
\hline $\begin{array}{l}\text { Nephrostomy tube insertion } \\
\text { and management }\end{array}$ & $\mathrm{OK}$ & $\mathrm{OK}$ \\
\hline
\end{tabular}


increased from $3 \%$ to $30 \%$ in one study ${ }^{30}$ and from $20 \%$ to $47 \%$ in another. ${ }^{31}$

Strengths of this study include some of the first modern data about hospice use in HM patients. A recent systematic review $^{32}$ found only three dated U.S. studies of HM and hospice. First, Lang and colleagues studied Medicare population (65 and over) with acute myelogenous leukemia using 1991-1999 data; we think this is not all that relevant, because only a small fraction $(21 \%-29 \%)$ got any chemotherapy, and it was all Medicare patients. ${ }^{33}$ Iwashnya studied the use of hospice by various groups using Medicare data from 1993, ${ }^{34}$ which did include about $20 \%$ HM patients, but the data are now 20 years old. Bruera's group examined the patterns of inhospital use of palliative care for HM patients, ${ }^{35}$ but did not include any data about eventual hospice use.

In addition, the collaboration of hospices and the cancer center made it possible to track our patient referrals. Weaknesses include the lack of a master registry and single electronic medical record of all HM patients with associated treatments and outcomes, such that patients must be crossmatched to capture and recapture events. It is possible that we missed blood transfusions from other providers, but unlikely, as nearly all care is delivered here.

In conclusion, the course of most patients with refractory HMs is predictable once cure is no longer possible, and the survival is not dissimilar from solid tumor patients with a sixmonth or less prognosis. ${ }^{36}$ Patients appear to be referred to hospice late or not at all. Those referred use few special or expensive services, but this could be due to patient selection or the late referral. More research is needed to better define the role of palliative care in the care of HM patients and to determine the optimal timing, duration, and type of hospice services to be provided, including the types of "expanded access" services appropriate for this population.

\section{Acknowledgments}

This research was made possible by the Harry J. Duffey Family Patient and Family Services Program of JH SKCCC, Baltimore, Maryland; and Gilchrist Hospice, Towson, Maryland. The research was supported by National Cancer Institute Cancer Center Core Grant to the SKCCC (CA006973).

We thank Nancy Cisar for continued excellent programmatic assistance. We thank Drs. Richard Jones, Richard Ambinder, and Judith Karp, the Gilchrist Hospice team, and Dr. Irene Higginson for helpful advice.

\section{Author Disclosure Statement}

There are no conflicts of interest noted by any of the authors.

\section{References}

1. Smith TJ, Temin S, Alesi E, et al.: American Society of Clinical Oncology provisional clinical opinion: The integration of palliative care into standard oncology care. J Clinical Oncol 2012;30:880-887.

2. Smith TJ, Schnipper LJ: The American Society of Clinical Oncology Program to Improve End-of-Life Care. J Palliat Med 1998;1:221.

3. Peppercorn JM, Smith TJ, Helft PR, et al.: American Society of Clinical Oncology statement: Toward individual- ized care for patients with advanced cancer. J Clin Oncol 2011;29:755-760.

4. Nelson C, Chand P, Soratais J, Oloimooja J, Rembert G: Inpatient palliative care consults and the probability of hospital readmission. Perm J 2011;15:48-51.

5. Equidanos S, Vesper E, Lorenz K: 30-day readmissions among seriously ill older adults. J Palliat Med 2012;15:1356-1361.

6. Fitch K, Pyenson P: Cancer patients receiving chemotherapy: Opportunities for better management. New York: Milliman, 2010.

7. Manitta VJ, Philip JAM, Cole-Sinclair MF: Palliative care and the hemato-oncological patient: Can we live together? S review of the literature. J Palliat Med 2010;13:1021-1025.

8. Chow K, Coyle N: Providing palliative care to family caregivers throughout the bone marrow transplantation trajectory: Research and practice: Partners in care. J Hosp Pall Nursing 2011;13:7-13.

9. Epstein AS, Goldberg GR, Meier DE: Palliative care and hematologic oncology: The promise of collaboration. Blood Rev 2012;26:233-239.

10. Grundy M, Ghazi F: Research priorities in haemato-oncology nursing: Results of a literature review and a Delphi study. Eur J Oncol Nurs 2009;13:235-249.

11. Lee SJ, Fairclough D: Discrepancies between patient and physician estimates for the success of stem cell transplantation. JAMA 2001;285:1034-1038.

12. Chantal JNM, Neil MJB, Sam A: What investigations and procedures do patients in hospices want? Interview based survey of patients and their nurses. BMJ 1997;315:1202-1203.

13. Mercadante S, Ferrera P, Villari P, David F, Giarratano A, Riina S: Effects of red blood cell transfusion on anemiarelated symptoms in patients with cancer. J Palliat Med 2009;12:60-63.

14. American Cancer Society: ACS Facts and Figures. American Cancer Society, 2010.

15. Ma X, Does M, Raza A, Main ST: Melodysplastic syndromes: Incidence and survival in the United States. Cancer 2007;109:1536-1542.

16. Earle CC, Chapman RH, Baker CS, et al.: Systematic overview of cost-utility assessments in oncology. J Clin Oncol 2000;18:3302-3317.

17. Smith TJ, Hillner BE: Bending the cost curve in cancer care. N Engl J Med 2011;364:2060-2065.

18. Riley GF, Lubitz JD: Long-term trends in Medicare payments in the last year of life. Health Serv Res 2010;45:565576.

19. Gaeta S, Price KH: End-of-life issues in critically ill cancer patients. Crit Care Clin 2010;26:219-227.

20. Kelley AS, Deb P, Du Q, Aldridge Carlson MD, Morrison RS: Hospice enrollment saves money for Medicare and improves care quality across a number of different lengthsof-stay. Health Aff 2013;32:552-561.

21. Christakis NA, Iwashyna TJ: The health impact of health care on families: A matched cohort study of hospice use by decedents and mortality outcomes in surviving, widowed spouses. Soc Sci Med 2003;57:465-475.

22. Morden NE, Chang CH, Jacobson JO, et al.: End-of-life care for Medicare beneficiaries with cancer is highly intensive overall and varies widely. Health Aff 2012;31:786796.

23. National Hospice and Palliative Care Organization: NCHPO Facts and Figures: Hospice Care in America. National Hospice and Palliative Care Organization, 2012. 
24. Center for Medicare and Medicaid Services: Medicare Hospice Data. www.cms.gov/Medicare/Medicare-Fee-ForService-Payment/Hospice/Medicare_Hospice_Data.html. Center for Medicare and Medicaid Services, 2013.

25. Teno JM, Casarett D, Spence C, Connor S: It is "too late" or is it? bereaved family member perceptions of hospice referral when their family member was on hospice for seven days or less. J Pain Symptom Manage 2012;43:732-738.

26. Furman CD, Doukas DJ, Reichel W: Unlocking the closed door: Arguments for open access hospice. Am J Hosp Palliat Care 2010;27:86-90.

27. Freund K, Weckmann MT, Casarett DJ, Swanson K, Brooks MK, Broderick A: Hospice eligibility in patients who died in a tertiary care center. J Hosp Med 2012;7:218-223.

28. Weckmann MT, Freund K, Bay C, Broderick A: Medical manuscripts impact of hospice enrollment on cost and length of stay of a terminal admission. Am J Hosp Palliat Care 2012;1-3.

29. Wittenberg-Lyles E, Diller A, Sanchez-Reilly S, Regehr K: Does exposure to palliative care prior to hospice make a difference for caregivers? J Palliat Med 2009;12:6.

30. Morrison RS, Dietrich J, Ladwig S, et al.: Palliative care consultation teams cut hospital costs for Medicaid beneficiaries. Health Aff 2011;30:454-463.

31. Meyer H: Changing the conversation in California about care near the end of life. Health Aff 2011;30:390-393.

32. Howell DA, Shellens R, Roman E, Garry AC, Patmore R, Howard MR: Haematological malignancy: Are patients appropriately referred for specialist palliative and hospice care? A systematic review and meta-analysis of published data. Palliat Med 2011;25:630-641.

33. Lang K, Earle CC, Foster T, Dixon D, Van Gool R, Menzin $\mathrm{J}$ : Trends in the treatment of acute myeloid leukaemia in the elderly. Drugs Aging 2005;22:943-955.

34. Iwashyna TJ, Zhang JX, Christakis NA: Disease-specific patterns of hospice and related healthcare use in an incidence cohort of seriously ill elderly patients. J Palliat Med 2002;5:531-538.

35. Fadul N, Elsayem A, Palmer JL, Tao Z, Braiteh F, Bruera E: Predictors of access to palliative care services among patients who died at a comprehensive cancer center. J Palliat Med 2007;10:1146-1152.
36. Salpeter SR, Malter DS, Luo EJ, Lin AY, Stuart B: Systematic review of cancer presentations with a median survival of six months or less. J Palliat Med 2012;15:175-185.

37. Kumar SK, Lee JH, Lahuerta JJ, et al.: Risk of progression and survival in multiple myeloma relapsing after therapy with IMiDs and bortezomib: A multicenter international myeloma working group study. Leukemia 2012;26:149157.

38. Witzig TE, Tang H, Micallef IN, Ansell SM, et al.: Multiinstitutional phase 2 study of the farnesyltransferase inhibitor tipifarnib (R115777) in patients with relapsed and refractory lymphomas. Blood 2011;118:4882-4889.

39. Kadia TM, Jabbor E, Kantarjian H: Failure of hypomethylating agent-based therapy in myelodysplastic syndromes. Semin Oncol 2011;38:682-692.

40. Al-ali HK, Jaekel N, Junghanss C, et al.: Azacitidine in patients with acute myeloid leukemia medically unfit for or resistant to chemotherapy: A multicenter phase I/II study. Leuk Lymphoma 2012;53:110-117.

41. Garg RJ, Kantarjian H, O’Brien S, Quintás-Cardama A, Faderl S, Estrov Z, Cortes J: The use of nilotinib or dasatinib after failure to 2 prior tyrosine kinase inhibitors: Long-term follow-up. Blood 2009;114:4361-4368.

42. Cortes J, Lipton JH, Rea D, et al.: Phase 2 study of subcutaneous omacetaxine mepesuccinate after TKI failure in patients with chronic-phase CML with T315I mutation. Blood 2012;120:2573-2580.

43. Wierda WG, Kipps TJ, Stilgenbauer S, et al.: Ofatumumab as single-agent CD20 immunotherapy in fludarabine-refractory chronic lymphocytic leukemia. J Clin Oncol 2010;28:17491755.

Address correspondence to: Thomas J. Smith, MD, FACP, FASCO, FAAHPM Johns Hopkins Medical Institutions Sidney Kimmel Comprehensive Cancer Center 600 N. Wolfe Street Block 369 Baltimore, MD 21287-0005

E-mail: tsmit136@jhmi.edu 